\title{
Gymnastik og opdragelse
}

\author{
af Else Trangbak
}

Gymnastikken er i dag en stor bevægelsesaktivitet, som især dyrkes af mange kvinder og piger. Aktiviteten defineres på mange måder forskelligt fra anden idrætsaktivitet, p.g.a. de forskellige prioriteringer af kvaliteter, såvel bevægelsesmæssigt som udtryksmæssigt. Gymnastikken opprioriterer det smukke, det æstetiske, det harmoniske og det sunde i bevægelserne og fremviser sig oftest i form af mange på et hold, som gør $\emptyset$ velser i takt eller i en relativ fastlagt koreografi. Dette gælder dog ikke for konkurrencegymnastikken, som her bliver opfattet som idræt og sport.

Gymnastikken er således i sit indhold og sin form modsætningsfyldt ved på den ene side at vægte sanselighed og opmærksomhed i det bevægelsesmæssige udtryk og på den anden side arbejde med former, der er tilrettelagte og forudsigelige.

Gymnastikken udøves i mange forskellige miljøer, skolen, de frivillige foreninger, de politiske oplysningsforbund og i kommercielle institutter. Indhold og form svarer på mange måder til hinanden, men de ydre rammer lokaler, faciliteter, beklædning, $\varnothing \mathrm{ko}-$ nomi m.m. er forskellige, og oplevelsen og prægningen af den enkelte deltager hænger sammen med en kombination af indhold, form og ydre rammer.

Gymnastikken i 1800-tallet undergik store og væsentlige forandringer, som rummer mange muligheder for perspektiveringer omkring gymnastikken i dag, så her er valgt at tage udgangspunkt i 1800-tallets ideer, indhold og arbejdsformer i gymnastikken samt betydningen af de ydre rammer, og herunder den påvirkning, som gymnastikken fik fra de andre gymnastikmiljøer.

\section{Gymnastikkens idéverden}

Den moderne gymnastiks opståen omkring 1800 skal ses i tæt tilknytning til oplysningspædagogernes ideer om, at den legemlige opdragelse skulle være en del af den samlede opdragelse. Forskellige pædagoger tog med hver sit udgangspunkt fat på at vurdere gymnastikkens muligheder i opdragelsen. De opstillede forskellige mål. I Danmark blev man, som i andre lande inspireret fra Tyskland og senere fra Sverige, og forholdet mellem de svenske og tyske opdragelsesidealer blev centrale i forbindelse med gymnastikkens brydninger i Danmark.

\section{Tysk gymnastik}

Tysk gymnastik er ikke nogen éntydig størrelse, som umiddelbart lader sig beskrive, men en gymnastik, der udfra nogle af filantropismens opdragelsesidealer udviklede sig i 1800-tallet i forskellige retninger, påvirket af den kulturelle og samfundsmæssige udvikling. Udgangspunktet var en humanistisk, rationalistisk og naturalistisk tankegang, med menneskelivet og troen på den fysiske opdragelses betydning i centrum. To tyske pædagoger satte udfra forskellige ideer deres præg på begrebet tysk gymnastik. 


\section{Den human-pædagogiske målsætning}

I 1793 udgav J.C.F. Gutsmuths den første håndbog i gymnastik »Gymnastik für die Jugend «. Bogen kom til at danne grundlaget for den moderne gymnastik, og Gutsmuths havde en human-pædagogisk målsætning, hvor barnets hele udvikling blev sat $\mathrm{i}$ centrum. Udfra disse synspunkter forsøgte han at opbygge et system, der var medicinsk begrundet, pædagogisk gennemtænkt og udført. Han valgte en alsidig gymnastik med legen i naturen og de naturlige bevægelser, som løb, spring og kast som det bevægelsesmæssige udgangspunkt. Man kan ikke tale om et egentlig øvelsessystem, men i højere grad et opdragelsessystem, hvor kernen var, at mennesket blev dannet af både krop og sjæl. Hans idè var, at der til et »legemligsgode«svarede en »sjælsgode«.
1) Legemlig sundhed
2) Hærdning

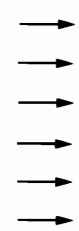
sjælsklarhed
mandighed
3) Styrke og dygtighed
åndsværværelse og mod
4) Legemlig virketrang
sjælelig virketrang
5) Legemsdannelse
sjælsskønhed
6) Skarpe sanser
tankekraft

\section{Idealet var at skabe hele mennesker.}

\section{Den samfunds-pædagogiske målsætning}

Inspireret af de nationalromantiske ideer i Tyskland i begyndelsen af 1800-tallet og under påvirkning af fransk overherredømme formulerede J.F.L. Jahn i »Deutsches Volkstum « målet frihed og enhed for de tyske stater. Han så folkeopdragelsen som et centralt middel, og heri indgik foruden historie og sprog også legems $\emptyset$ velser, som han gav navnet »turn«. Han arbejdede videre med Gutsmuths øvelsesstof, men dertil kom, at han begyndte at systematisere det gymnastiske miljø i turnpladsen, som var en $\emptyset$ velsesplads med redskaber, foredragsplads m.m. Han gav endvidere indholdet en anden opdragelsesmæssig ramme, idet han foretog en tvedeling af træningstiden i en obligatorisk og en fri del. I den obligatoriske del indgik fælles krops $\varnothing$ velser, mens turnerne i den frie del arbejdede selvstændigt i de redskaber, der fandtes på turnpladsen. Han opfandt redskaberne barre og reck, men $\emptyset$ velserne fremkom gennem gymnasternes eksperimenter. Ideen bag den frie del var at opdrage turnerne til selvstændige og initiativrige personer, som i givet fald ville kunne tage hurtige beslutninger i pressede situationer.

\section{Idealet var at skabe handlende mennesker.}

\section{Svensk gymnastik}

I lighed med tysk gymnastik kan man ikke tale om svensk gymnastik som et èntydigt begreb, idet systemet undergik forandringer, men udgangspunktet var P.H. Lings nationalromantiske tanker, som kom til udtryk gennem hans digtning og gymnastikpædagogiske arbejde. P.H. Ling fik kun i begrænset omfang nedskrevet sine øvelser, hvilket derimod hans søn Hjalmar Ling gjorde.

\section{Den fysiologisk-pædagogske målsætning}

P.H. Ling begyndte $\mathrm{i}$ begyndelsen af 1800 -tallet at systematisere det gymnastiske $\emptyset$ velsesstof udfra en anatomisk og fysiologisk tankegang. I forlængelse heraf udviklede 
man i Sverige i løbet af 1800-tallet et Øvelsessystem, der som mål havde at sikre kroppens rationelle træning. P.H. Lings ideal var, i lighed med f.eks. Gutsmuths, menneskets hele udvikling, men den begyndende rationelle tankegang medførte en opsplitning mellem opdragelsen af kroppen og sjælen.

\section{Idealet var at træne kroppen rationelt.}

De idealer, som de førende gymnastikpædagoger fremførte i begyndelsen af 1800tallet strakte sig fra en helhedsopfattelse til en rationel opfattelse af forholdet mellem kroppen og sjælen.

\section{Helhedsopfattelse:}

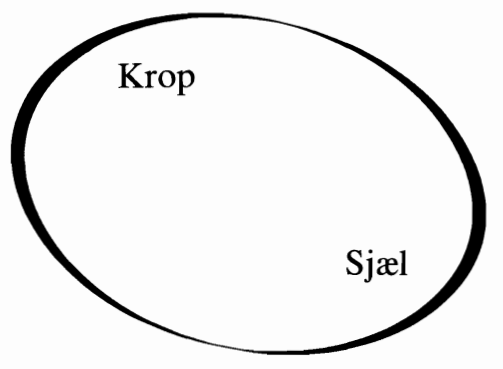

Rationel opfattelse :

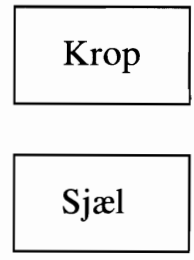

\section{Begrebernes foranderlighed i 1800-tallet}

Gymnastikbegrebet ændrede sig i Danmark, som i de fleste andre lande i løbet af 1800-tallet, fra at være alsidigt aktivitetsbegreb, omfattende sammensatte bevægelser indenfor forberedende $\emptyset v e l s e r, ~ l ø b e-$, springe-, kaste- og svømme $\emptyset$ velser, udtrykt gennem den tyske pædagogiske gymnastik, til ved århundredets afslutning af have udskilt sig som et område udelukkende med konstruerede, formgivende $\emptyset$ velser, i form af svensk gymnastik.

\section{Gymnastikbegrebets}

\section{andring}

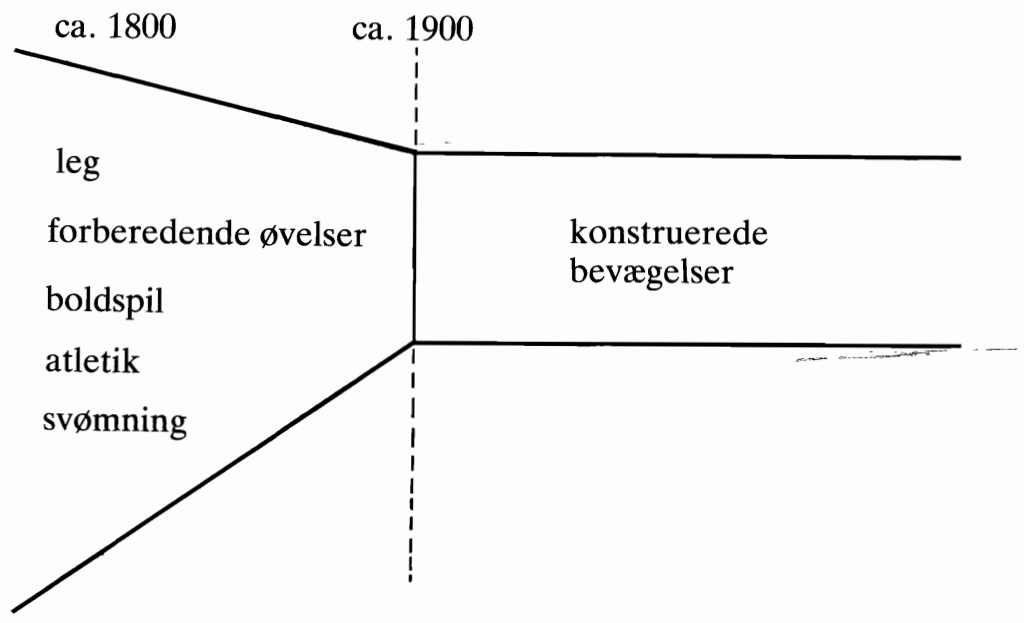




\section{Pædagogikkens forandring}

I takt med denne ændring forandredes opfattelsen af, hvad der var pædagogisk i gymnastisk sammenhæng. Den tyske pædagogiske gymnastik tog udgangspunkt $i$, at den bedste målstok for gymnastikken skulle være elevernes egen lyst, hvorimod man i den svenske gymnastik tog udgangspunkt $i$, at mennesket skulle lære at sætte sin krop under sin egen vilje gennem arbejdet med rigtige $\emptyset v e l s e r$. For at kunne styre $\emptyset$ velsernes rigtige udførelse blev kommandoerne i den svenske gymnastik helt centrale. Man kan tale om et brud i pædagogikbegrebet fra at tale om en rigtig undervisning til at tale om rigtige $\varnothing v e l s e r$. Teorien i den tyske gymnastik i 1800-tallet blev søgt i såvel human-pædagogiske som national-pædagogiske ideer med udgangspunkt i legens betydning for opdragelsen, hvorimod den svenske gymnastik gennem »naturvidenskabelige« $\emptyset$ velser fortalte, hvad der var rigtigt og forkert og sikrede $\emptyset$ velsernes gennemførelse med fast og hård disciplin via kommandoerne. Gymnastikken var hermed også blevet moralskopdragende og militært disciplinerende.

Den tyske gymnastiks uforudsigelige muligheder var blevet erstattet af den svenske gymnastiks forudsigelighed m.h.t. såvel indhold som form.

\section{Miljøernes forandring}

Udover at gymnastikkens indhold og arbejdsform ændrede karakter i 1800-tället blev der skabt nye og andre miljøer for gymnastisk udfoldelse.

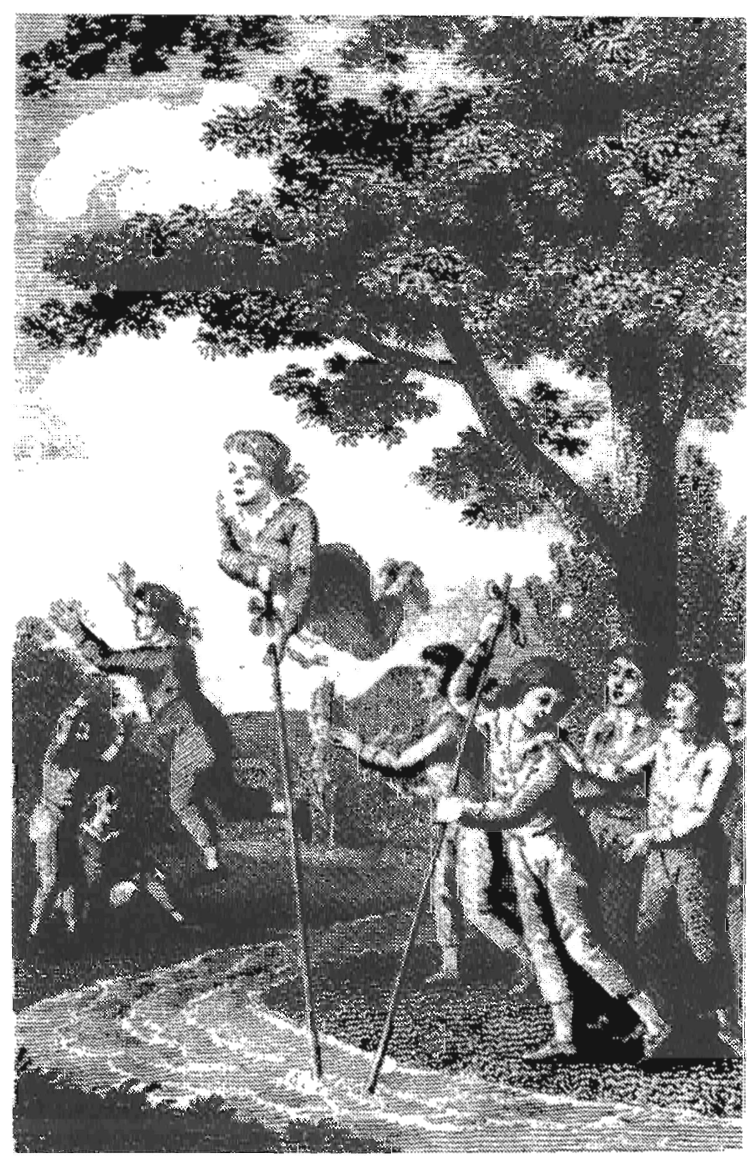

Gutmuths havde taget udgangspunkt $i$ bornenes leg $i$ den »agte" natur. (Kobberstik taget fra Gymnastik für die Jugend Schnepheltal 1793). 


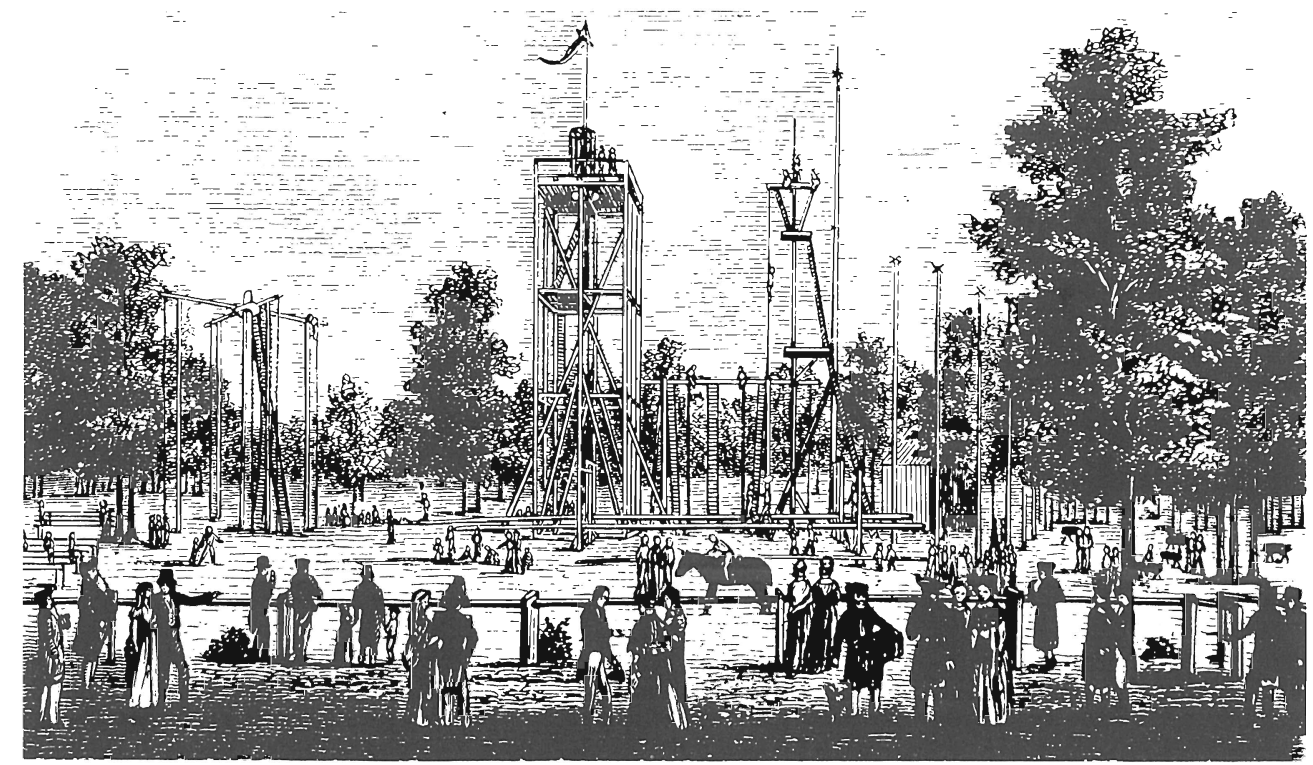

(Illustration fra turnpladsen på Hasenheide. Fra Else Trangbaks undersøgelse af Fl. Jahns nationale og gymnastikpadagogiske virksomhed i speciale på Historisk Institut Københavns Universitet 1979).

Jahn fors $\phi$ gte at systematisere naturen som miljø for hans turnere, mens den svenske gymnastik førte gymnastikken indendørs og udviklede her nye typer af redskaber, eks. rudestiger, ribber, flytbare bomme.

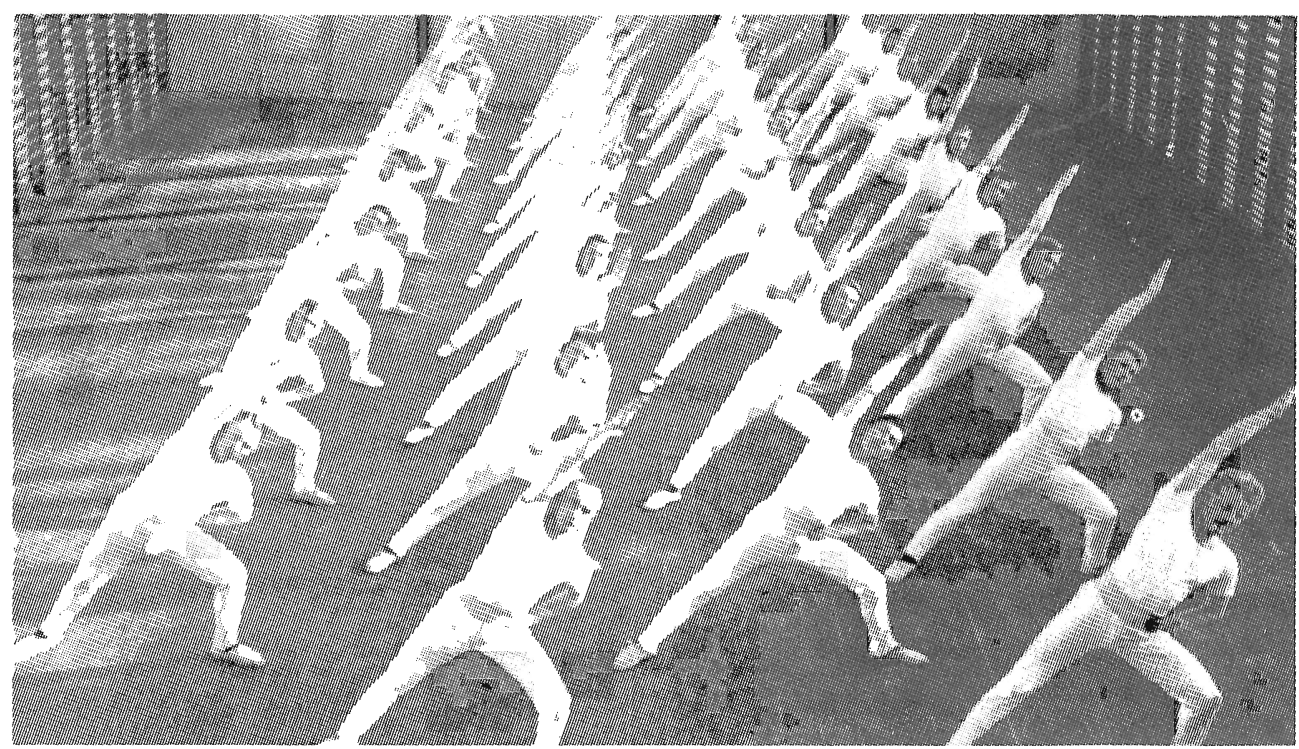

(Illustration af svensk gymnastik fra Ove Korsgård, "Kampen om kroppen«, København 1982 s. 228).

Gymnastikkens rammer blev således ændrede fra den fri natur, via den dresserede natur og til indendørs miljøer. 


\section{Dansk udvikling}

Man kan ikke tale om dansk gymnastik som et system, men derimod som den gymnastik der inspireret udefra udviklede sig i Danmark gennem 1800-tallet. Franz Nachtegall blev den initiativtager, der fors øgte at organisere gymnastikken i privat, skole og militært regi. Udviklingen af dansk gymnastik i 1800 -tallet kan opdeles i 3 perioder udfra såvel organisering som de centrale problemstillinger.

\section{Gymnastikkens etableringsfase. Ca. 1800 til 1860.}

Gymnastikken blev i denne periode institutionaliseret i skole og militært regi, hvoraf kun skolen her vil blive omtalt. Faget blev indført som et alment dannende fag, både for drenge og piger, men blev i 1828 indskrænket til kun at omfatte drenge. En indskrænkning, der varede til 1899, hvor pigerne fik mulighed for at dyrke gymnastik, og 1904, hvor faget endelig blev gjort obligatorisk også for pigerne.

På trods af at faget i etableringsfasen var blevet obligatorisk for drenge, og havde fået en faginspektion, som via årlige indberetninger fra skoledirektionerne fortalte, at det gik godt, var det reelle billede noget anderledes. Faget havde vanskeligt ved at leve op til lovens human-pædagogiske idealer p.g.a. de ydre forhold, mangelen på lærerkræfter, lokaler, og en helt naturlig skepsis fra befolkningens side om fagets nytte for.landalmuens børn. Skolegymnastikkens mangelfulde udvikling var medvirkende til, at der i 1858 i folketinget blev stillet forslag om fagets bortfald. Forslaget blev vedtaget i folketinget, men nedstemt $\mathrm{i}$ landstinget, og dermed var faget fortsat med i fagkredsen.

Den gymnastik man dyrkede var inspireret af Gutsmuths tyske pædagogiske gymnastik, der bestod af sammensatte bevægelser som løb, spring, kast og forskellige lege. $\emptyset$ velserne blev suppleret med de specielle »danske« smidigheds $\emptyset$ velser, en $\emptyset v e l s e s-$ gruppe som siden har været karakteristisk for dansk gymnastik. Øvelserne svarer nærmest til vore dages springøvelser på måtte, f.eks. kraftspring, flik-flak, hovedspring. De pædagogiske principper bag undervisningen tog udgangspunkt i børnenes lyst som vigtigste drivkraft $\mathrm{i}$ arbejdet.

\section{Gymnastikkens stabiliserings- og udviklingsfase. Ca. 1860 - 1880.}

Fra ca. 1860 og frem til 1880 blev der etableret nye gymnastikmiljøer, højskolerne, skytteforeninger, private gymnastikinstitutter og frie gymnastikforeninger, som udfra forskellige mål tog gymnastikken op.

\section{Gymnastikkens organisering:}

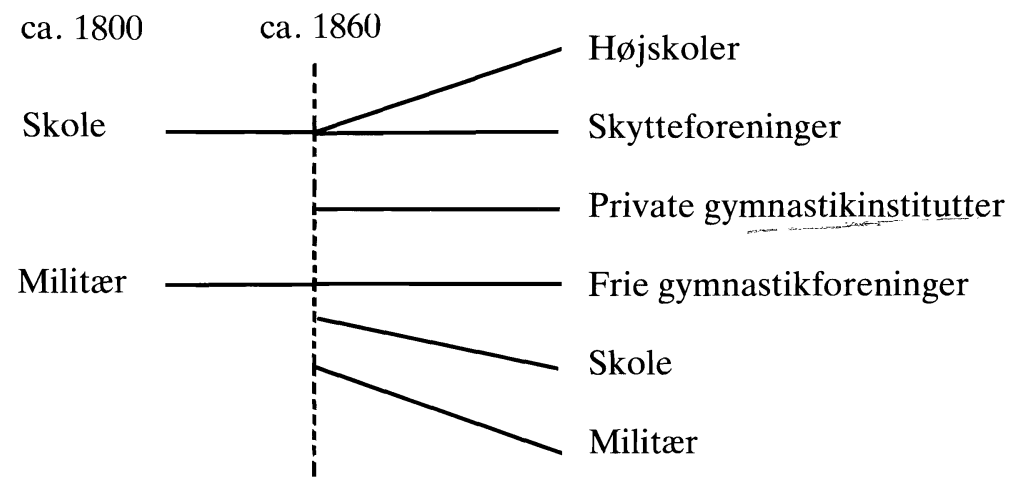


Højskolernes mål var primært folkelig oplysning, og det faldt ikke umiddelbart naturligt at optage gymnastikken i fagkredsen. Alligevel var gymnastikken med helt tilbage til de første højskoler og indgik for at adsprede og more eleverne, mellem det meget stillesiddende arbejde. Den nationale rejsning i begyndelsen af 1860 'erne kom gennem gymnastikken til at knytte højskolerne og skytteforeningerne sammen udfra ideen om, at »ægte Højskolesag og den ægte Skyttesag « her kunne forenes. Samarbejdet kom også til udtryk ved, at højskolerne allerede i 1878 engagerede sig i uddannelsen af delingsførere til skytteforeningerne. Et arbejde, der skulle vise sig at få stor betydning for gymnastikkens udbredelse.

Skytteforeningernes mål var af nationalpædagogisk karakter, og midlet blev skydning og eksercits. Gymnastikken kom dog meget tidligt med for bl.a. at sikre sammenholdet i vintermånederne, hvor skydningen måtte ophøre. I begge disse miljøer valgte man de $\emptyset$ velser, som man kendte fra skolen, d.v.s. de af Gutsmuths inspirerede $\emptyset$ velser suppleret med de danske smidigheds- og spring øvelser. Fælles for højskoler og skytteforeninger var, at de primært henvendte sig til ungdommen på landet.

De private gymnastikinstitutter opstod tilbage til 1860 , og henvendte sig som det eneste af miljøerne især til kvinder. Man forsøgte her, gennem fysisk aktivitet, at danne en modvægt mod svækkelsestendenser, i form af skæve rygge og svagt udviklet muskulatur. Man begyndte nu for første gang i Danmark at vurdere de forskellige gymnastiksystemers mulighed for at forbedre sundheden som det primære mål. Valget faldt her på blandingssystemer eller svensk gymnastik. Institutternes største fortjeneste skal ses i deres indsats i forbindelse med uddannelsen af kvindelige lærerinder.

De frie gymnastikforeninger, som i lighed med de private gymnastikinstitutter opstod i byerne, tog for første gang i Danmark fat på at arbejde med de tyske turnøvelser inspireret fra Jahn. Jahns nationalpolitiske målsætning blev ikke overført til Danmark, men kun de af ham inspirerede øvelser. Målet blev i foreningerne at underholde, adsprede og give børn og unge sunde kropsøvelser som kompensation for kedsomhed og for meget stillesiddende arbejde.

Fælles for alle miljøerne blev, på trods af store forskelle forårsaget af meget forskellige muligheder m.h.t. økonomi, lokaler og lærerkræfter, at de gav deltagerne gode og sammenhængende oplevelser. Gymnastikken blev her en del af en helhed på linie med de forskellige miljøers fester, præsentationer, foredrag og andet foreningsliv.

Skolegymnastikken blev i denne periode stabiliseret. De problemer, der opstod, omhandlede dog fortsat de meget vanskelige ydre vilkår, faget led under. Faget blev i denne periode præget af det nationalpolitiske ønske om revanche overfor Tyskland.

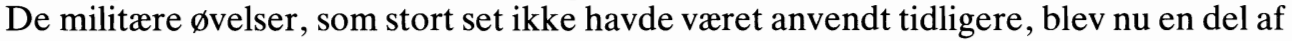
den obligatoriske undervisning, og det blev tilladt, at militært uddannede gymnastiklærere nu kunne undervise på de civile seminarier. De pædagogiske regler bag faget tog fortsat udgangspunkt i tysk gymnastik med lysten som drivkraften i arbejdet.

Gymnastikken blev i denne periode etableret $\mathrm{i}$ alle de nye miljøer udfra forskellige mål. Det gymnastiske indhold svarede i stor udstrækning til hinanden, dog var der forskelle mellem land og by, især forårsaget af de ydre rammer. Tysk gymnastik var fortsat hovedinspiratoren til det gymnastiske arbejde i Danmark, men den svenske gymnastik blev i perioden kendt indenfor kvindegymnastikken på højskolerne, de private gymnastikinstitutter, og i de frie gymnastikforeninger. Sålænge målet var hele og handlende 
mennesker henvendte gymnastikken sig primært til mænd, men på det tidspunkt lægerne begyndte at registrere, at kvindens krop led under en manglende fysisk opdragelse, og kvindens sundhed var truet, begyndte man, i privat regi, at tage kvindegymnastikken op.

Diskussionerne og problemerne i denne periode handlede stort set aldrig om det gymnastiske indhold, men derimod de ydre rammer, især lokaler og mangelen på kvalificerede lærerkræfter. Også på dette område udgør kvindegymnastikken en undtagelse, idet man her forsøgte at analysere sig frem til det mest effektive system til at løse de fysiske problemer.

\section{Gymnastikkens brydningsfase. Ca. 1885 - 1900.}

I modsætning til den tidligere periode kom det gymnastiske indhold nu i fokus. Stridighederne, som de udspillede sig fra ca. $1885 \mathrm{og}$ århundredet ud, omhandlede forholdet mellem »dansk « og svensk gymnastik. På baggrund af det mangeårige kendskab i de forskellige gymnastikmiljøer kan det være vanskeligt at forstå, hvorfor det netop fra midten af 1880'erne (som det oftest er blevet formuleret: efter en opvisning på Vallekilde Højskole i 1884) skulle lykkes den svenske gymnastik at vinde indpas i Danmark. Det lader sig også kun gøre i relation til den politiske situation i landet mellem Højre og Venstre.

Stridighederne kom til at omhandle flere forhold, de politiske, de skolepolitiske og de uddannelsespolitiske. Den politiske, som tog sin begyndelse under riffelprovisiorierne, var primært en intern strid i skytteforeningerne, men kom til at danne udgangspunktet for stridighederne på de andre områder. Allerede inden striden var afsluttet, blev den overført til det skole- og uddannelsespolitiske område, hvor der blev nedsat to kommissioner, hvis arbejde bar præg af de politiske modsætninger. Resultatet af kommissionernes arbejde blev den til skolen autoriserede Håndbog, der udkom i 1899. Håndbogen havde taget udgangspunkt i principperne for den svenske rationelle gymnastik. Det pædagogiske idègrundlag havde ændret karakter fra det humanpædagogiske til det fysiologisk-pædagogiske, fra at tage udgangspunkt i barnèts lyst og behov til at sætte kroppens krav og pligter i centrum.

Den svenske gymnastik var i disse politiske stridsår med til at sikre sammenholdet i skytteforeningerne, og blev her en del af landbefolkningens politiske bevidsthed. Den svenske gymnastik blev modstykket til dansk gymnastik og fremhævet som demokratisk overfor den danske militære gymnastik. Systemets gennemslagskraft er ofte blevet knyttet til »indførelsen « af det rigtige system, den svenske gymnastik, men det hang i langt højere grad sammen med de politiske forhold i landet, de svenskvenliges enorme begejstring, deres taktiske manøvrer og deres gode kontakter til især venstrepolitikere. Bymiljøerne var i befolkningens bevidsthed og reelt nærmere knyttet til Højre, og dermed blev bygymnastikkens tilknytning bevidsthedsmæssigt også til Højre i modsætning til gymnastikken på landet, som blev opfattet som en demokratisk venstregymnastik.

Man må her spørge, hvori bestod det demokratiske? Var det knyttet til indholdet, arbejdsformerne eller de samfundsmæssige rammer, gymnastikken indgik i?

\section{Forholdet mellem skolegymnastikken og den frivillige gymnastik}

Med de nye gymnastikmiljøer, der dukkede op i sidste halvdel af 1800-tallet, fik skolegymnastikken for første gang en konkurrent. Elevernes og befolkningens bevidsthed i forbindelse med faget kunne nu lidt efter lidt skabes i relation til såvel skolen som fri- 
tiden. De nye miljøer kunne, på trods af store forskelligheder, sikre sammenhængende oplevelser for deltagerne, idet aktivitet, foredrag, fester og foreningsliv gik hånd $\mathrm{i}$ hånd.

Skolegymnastikkens ydre rammer var begrænsede, en enkelt time hist og her, uden sammenhæng med skolens øvrige liv, de andre fag og med lærerkræfter, der kun i begrænset omfang tilhørte skolens samlede liv og erfaringsbaggrund, med det resultat at deltagernes oplevelser blev vidt forskellige i skole og fritid. Når den svenske gymnastik på højskolerne og i skytteforeningerne fik så stor succes og gennemslagskraft, hang det mere sammen med den politiske bevidsthed, der blev knyttet til systemet, og de ydre rammer, den fungerede under. Men for skolegymnastikkens trange ydre rammer blev overgangen til den meget fysiologiske gymnastik, der satte kroppens behov over barnets hele udvikling og disciplin og orden over leg og spontanitet, et nederlag.

\section{Perspektiveringer for gymmastikken i dag}

I perioden frem til 1960 udviklede gymnastikken sig kvantitativt. Der kom mange nye medlemmer især i de frivillige foreninger, men også i de andre miljøer, som hver især blev udbyggede og undergik forandring. Gymnastikken var som begreb blevet indsnævret og idrætten blevet udskilt som et selvstændigt område. Det bet $\emptyset$, at uđover påvirkningen og dialogen mellem skolegymnastikken og den frivillige gymnastik, måtte der nu også etableres en dialog og konkurrence imellem gymnastikken og idrætten om medlemmerne i skole og fritid.

Resultatet af gymnastikkens kvalitative forandring blev, at kvinderne helt tilbage fra 1930'erne begyndte at få overtaget i gymnastikken, hvilket medførte store forandringer i det gymnastiske indhold. Kropsligheden begyndte at få nye dimensioner og harmoni, rytmik og æstetik kom i focus.

1960'ernes generelle opbrud i kønsroller og idrættens voldsomme ekspansion medførte, at gymnastikken i dag næsten helt er overtaget af kvinder og børn. Hvor den politiske kamp i slutningen af 1800-tallet og dialogen mellem de forskellige miljøer var

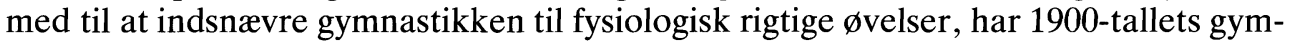
nastik indgået $i$ dialog og konkurrence med andre og nye miljøer, som hver på sin måde har påvirket indhold og form. Her skal kun nævnes skolens og dansens påvirkning, hvor skolegymnastikken og -idrættens idealer om treenigheden mellem fysiske, psykiske og sociale aspekter i undervisningen har været med til at sætte focus på idealet om hele og handlende individer. Dansen har også påvirket og inspireret såvel det gymnastiske indhold som dens arbejds- og udtryksformer med det resultat, at de stive og disciplinerende former og udtryk er ved at forsvinde. Gymnastikkens ideal svarer i dag bedre til Gutsmuths idéverden om hele mennesker skabt gennem fysisk aktivitet med legen og spontaniteten som inspiration i det pædagogiske arbejde. Hvor legen tidligere inddrog rekvisitter og redskaber er legen med kroppen og dens udtryksmåder i dag i centrum.

Gutsmuths sagde det så smukt: »Jeg er et hele ikke et fragment «.

De kommercielle miljøer, som i dag dyrker gymnastik, har i høj grad ladet sig inspirere af den fysiologiske-rationelle indfaldsvinkel udfra ideen om rigtige øvelser, et rigtigt udseende og en rigtig ramme. Vi skal blot overgive os i autoriteternes vold, så skal det nok gå os godt. 
Man kan, måske lidt polemisk, slutte med at stille spørgsmålet, om gymnastikken ikke har bevæget sig tilbage til Gutsmuths og Jahns idealer, mens sporten og de kommercielle miljøer har overtaget den svenske gymnastiks rationelle tankegang, i dens stræben efter den mest effektive arbejdsform for at yde den rigtige og maximale præstation?

\section{Anvendt litteratur:}

Artiklen er primært skrevet på baggrund af min licentiatafhandling: Gymnastikken i 1800-tallet mellem ide og virkelighed, afleveret december 1986 på Historisk Institut, Københavns Universitet. (Vil udkomme i bogform i løbet af 1987). Litteraturhenvisninger vil derfor bedst og fyldigst kunne findes deri.

Else Trangbak, cand. mag. i historie og idrat, adjunkt på Danmarks Højskole for Legems $\varnothing$ velser. Formand for Dansk Idratshistorisk Forening Krop og Kultur. 